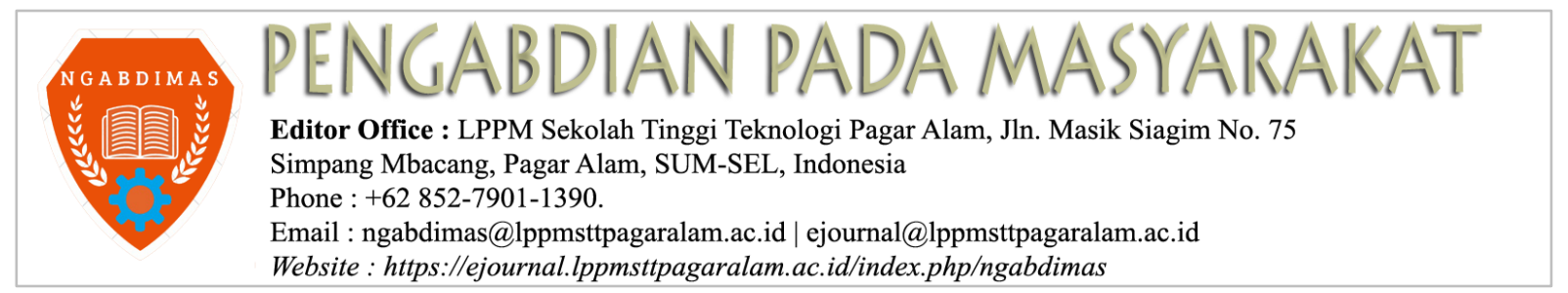

\title{
Pelatihan Pembuatan Blog Bagi Guru SMA Negeri 2 Pagar Alam
}

\author{
Yogi Isro' Mukti \\ Program Studi Teknik Informatika; Sekolah Tinggi Teknologi Pagaralam (STTP) \\ Jl. M. Siagim No.75 Kel. Karang Dalo, Dempo Tengah, Kota Pagar Alam \\ Telp/Fax: (0730) 621916 \\ e-mail: Yogie.Isro.mukti@gmail.com.
}

\begin{abstract}
Abstrak
Pengabdian menjadi satu dharma yang harus dilakukan oleh civitas perguruan tinggi seperti STTP sehingga semangat berbagi dibangkitkan terus menerus dan pelatihan pembuatan blog ini merupakan semangat itu yang ada pada civitas STTP dilaksanakan pada SMAN 2 Kota Pagaralam yang sangat membutuhkan pelatihan untuk membuat sistem pendukung pembelajaran berbasis internet, bagi SMAN 2 Kota Pagaralam pendukung pembelajaran menggunakan blog sangat penting untuk agar sistem pembelajaran menjadi semakin baik dan mengena kepada para siswa karena dengan blog dan internet siswa bisa mengulang pelajaran yang sudah dipelajari dikelas dengan membuka blog mata pelajaran tertentu yang belum terlalu memahami pada saat dalam kelas, pelatihan dilakukan dengan model seperti seminar artinya dengan penjelasan, dilanjtkan dengan praktek pembuatan blog pendukung pembelajaran. Agar pelatihan pembuatan blog ini mengena maka dilakukan pre dan pos tes, pre tes untuk mengetahui kemampuan awal sebelum pelatihan dan hasilnya para peserta mengetahui teknologi pendidikan yang berbasis blogging tetapi tidak bisa membuatnya, selanjutnya diakhir pelatihan dilakukan pos tes hasilnya peserta pelatihan maтри membuat media pembelajaran menggunakan sarana blog, dan merasa nyaman memberikan sarana tambahan dengan blog.
\end{abstract}

Kata kunci-Pengabdian, Civitas, Siswa, Blog, Guru, Pelatihan.

\section{PENDAHULUAN.}

Website dan blogging telah benar-benar menjadi penyebar informasi yang sangat efektif ditengah arus informasi yang sangat cepat saat ini, perkembangan teknologi informasi dan komunikasi khususnya internet saat ini sangat memperngaruhi gaya hidup manusia, salah satunya Blog ini yang merupakan salah satu fasilitas dari pemanfaatan internet. Media ini sangat banyak sekali digunakan di setiap bidang kehidupan. Tak luput salah satu bidangnya blog untuk Pendidikan, baik itu bersifat pribadi maupun institusi, Blog (Web Log) merupakan sarana untuk menyimpan informasi secara online yang dapat digunakan oleh siapa saja, dapat memberikan semua informasi tanpa batas ruang dan waktu.

Blog atau Web Log adalah catatan pribadi yang dapat ditulis di internet, berisi berupa informasi dan sering di update penggunanya secara kronologis (menurut waktu) blog bisa dikatakan sebagai buku harian.Namun blog perbedaannya blog dapat dibaca oleh siapa saja, tulisan blog dapat berupa fokus pada satu bidang informasi saja, misal seperti politik, budaya, teknologi, olah raga, pendidikan dan lain-lain. Namun blog juga bisa berupa jurnal pribadi yang berisi tentang kisah seseorang yang mempunyai blog tersebut pada kehidupan sehari-harinya.

Penggunaan blog yang sangat luas ini memberikan kesempatan kepada guru dan karyawan SMAN 2 Kota Pagar Alam mengaplikasikan blog untuk berbagai hal terutama diaplikasikan untuk keperluan pendukung pembelajaran ini, blog menjadi alternative menyampaikan materi untuk mendukung kegiatan belajar dalam kelas, dengan dukungan blog siswa dapat membuka kembali materi yang sudah dipelajarinya dimana saja dan kapan saja. Dari pemaparan diatas dituntut agar para Guru bidang studi harus selalu meningkatkan kualitas pembelajaran dengan menggunakan 
semua resource terkait, sehingga dipandang perlu untuk diadakan pelatihan blogging ini pada SMAN 2 karena dapat memberikan nilai tambah bagi SMAN 2.

\section{METODE.}

Metode pelaksanaan pengabdian yang dilakukan dengan cara seluruh peserta pelatihan menyimak (menonton) bersama, membaca bersama (modul pelatihan), memahami tools aplikasi (Software) dan berinteraksi secara langsung (Aplikatif) dengan software.

\subsection{Pengabdian.}

Pengabdian merupakan kegiatan rutin yang harus dilaksanakan oleh civitas perguruan tinggi sebagai perwujudan atau pengamalan dari Tri Dharma Perguruan Tinggi yang harus dilakukan, tujuannya membantu dan menemukan solusi terhadap seluruh permasalahan yang ada pada tempat dimana civitas perguruan tinggi itu melakukan pengabdian, lebih detail diantara tujuan tersebut adalah sebagai berikut:

1. Melaksanakan program mengentaskan masyarakat tersisih (preferential option for the poor) pada semua strata, yaitu masyarakat yang tersisih secara ekonomi, politik, sosial, dan budaya;

2. Menciptakan inovasi teknologi untuk mendorong pembangunan ekonomi Indonesia dengan melakukan komersialisasi hasil penelitian;

3. Memberikan solusi berdasarkan kajian akademik atas kebutuhan, tantangan, atau persoalan yang dihadapi masyarakat, baik secara langsung maupun tidak langsung;

4. Melakukan alih teknologi, ilmu, dan seni kepada masyarakat untuk pengembangan martabat manusia dan kelestarian sumber daya alam.

\subsection{Multimedia Pembelajaran.}

Multimedia merupakan media menggabungkan dua unsur atau lebih media terdiri dari teks, grafis, gambar, foto, audio, video dan animasi secara terintegrasi. Multimedia terbagi dua kategori, yaitu: multimedia linier dan multimedia interaktif. Multimedia linier suatu multimedia yang tidak dilengkapi dengan alat pengontrol apapun yang dapat dioperasikan penguna. Multimedia ini berjalan sekuensial (berurutan), contohnya: TV dan film. Menurut Rosch Multimedia dapat diartikan sebagai kombinasi dari komputer dan video (Rosch, 1996). Kombinasi dari paling sedikit dua media input atau output. Media ini bisa berupa audio (suara, musik), animasi, video, teks, grafik dan gambar (Turban dkk, 2002) Hofstetter mengatakan, multimedia pemanfaatan komputer untuk membuat dan menggabungkan teks, grafik, audio, gambar bergerak (video dan animasi) dengan menggabungkan link dan tool memungkinkan pemakai melakukan navigasi, berinteraksi, berkreasi dan berkomunikasi.

Multimedia interaktif suatu multimedia yang dilengkapi dengan alat pengontrol yang dapat dioperasikan pengguna, sehingga pengguna bisa memilih yang dikehendaki untuk proses selanjutnya. Contoh multimedia interaktif adalah: multimedia pembelajaran interaktif, aplikasi game, dll. Sedangkan pembelajaran diartikan sebagai proses penciptaan lingkungan yang memungkinkan terjadinya proses belajar. Jadi pada pembelajaran yang utama bagaimana siswa belajar. Belajar dalam pengertian aktifitas mental siswa dalam berinteraksi dengan lingkungan menghasilkan perubahan perilaku bersifat relatif konstan. Secara sederhana multimedia diartikan sebagai lebih dari satu media. Arti multimedia umumnya dikenal saat ini berbagai macam kombinasi grafis, teks, suara,video, dan animasi. Penggabungan ini merupakan suatu kesatuan yang secara bersama menampilkan informasi, pesan, atau isi pelajaran. Konsep penggabungan ini dengan sendirinya memerlukan beberapa jenis peralatan perangkat keras yang masing-masing tetap menjalankan fungsi utamanya sebagaimana biasanya, dan komputer merupakan pengendali seluruh peralatan itu. Multimedia bertujuan menyajikan informasi dalam bentuk menyenangkan,menarik, mudah dimengerti, dan jelas.

\subsection{Blogging.}

Istilah Weblog kemudian disingkat menjadi Blog sebenarnya mulai dikenal sejak tahun 1997, tetapi baru populer tahun 2000. Blog bentuk aplikasi web yang menyerupai tulisan (yang dimuat sebagai posting) pada halaman web umum. Tulisan ini dimuat dalam urut terbalik (isi terbaru dahulu baru kemudian diikuti isi yang lebih lama), meskipun tidak selamanya demikian. 
Saat ini, Blog menjadi bagian tak terpisahkan dari WWW dan dunia per-internet-an. Blog mulai dijadikan sebagai sumber berita koran, majalah, radio, bahkan televisi juga sudah menyiarkan beritanya lewat Blog mereka. Dunia pendidikan pun sudah banyak menampilkan materi pendidikan di Blog yang dibuat khusus maupun tidak khusus untuk dunia pendidikan. Di Blog para pengajar maupun pihak yang berkecimpung dalam dunia pendidikan mem-posting materi yang mereka anggap berguna bagi pencari informasi pendidikan. Sedangkan pencari informasi pendidikan pun dapat berpartisipasi mengembangkan maupun sekedar memberikan komentar isi Blog.

\section{Jenis-jenis Blog}

1. Blog politik: Tentang berita, politik, aktivis dan persoalan berbasis blog (Seperti kampanye).

2. Blog pribadi: Disebut juga buku harian online yang berisikan tentang pengalaman keseharian seseorang, keluhan, puisi atau syair, gagasan jahat, dan perbincangan teman.

3. Blog bertopik: Blog yang membahas tentang sesuatu, dan fokus pada bahasan tertentu.

4. Blog kesehatan: Lebih spesifik tentang kesehatan. Blog kesehatan kebanyakan berisi tentang keluhan pasien, berita kesehatan terbaru, keterangan-ketarangan tentang kesehatan, dll.

5. Blog sastra: Lebih dikenal sebagai litblog (Literary blog).

6. Blog perjalanan: Fokus pada bahasan cerita perjalanan yang menceritakan keteranganketerangan tentang perjalanan/traveling.

7. Blog riset: Persoalan tentang akademis seperti berita riset terbaru.

8. Blog hukum: Persoalan tentang hukum atau urusan hukum;

9. Blog media: Berfokus pada bahasan kebohongan atau ketidakkonsistensi media massa; biasanya hanya untuk koran atau jaringan televise.

10. Blog agama: Membahas tentang agama.

11. Blog pendidikan: Biasanya ditulis oleh pelajar atau guru.

12. Blog kebersamaan: Topik lebih spesifik ditulis oleh kelompok tertentu.

13. Blog petunjuk (directory): Berisi ratusan link halaman website.

14. Blog bisnis: Digunakan pegawai atau wirausahawan untuk kegiatan promosi bisnis mereka.

15. Blog pengejawantahan: Fokus tentang objek diluar manusia; seperti anjing.

16. Blog pengganggu (spam): Digunakan untuk promosi bisnis affiliate.

\subsection{Pemanfaatan Blog Sebagai Sumber Belajar.}

a. Pengertian Pemanfaatan

Pada kehidupan sehari-hari manusia tidak dapat terlepas dari kata belajar, baik itu belajar dalam lingkungan formal maupun belajar di lingkungan non-formal. Saat manusia belajar sesuatu maka mereka secara sadar maupun tidak sadar telah memanfaatkan sumber belajar yang ada berupa buku, tv, radio, manusia, bahkan internet.

\section{b. Pengertian Sumber Belajar}

Sumber belajar adalah apa saja (orang, bahan, alat, teknik, lingkungan) yang mendukung serta memungkinkan memberikan kemudahan dan kelancaran terjadinya belajar, serta memungkinkan terjadinya interaksi antara pebelajar dengan sumber belajar tersebut. Sumber belajar dikelompokan menjadi dua bagian, yaitu :

- Sumber belajar yang sengaja direncanakan (learning resources by design).

- Sumber belajar yang karena dimanfaatkan (learning resources by utilization).

Perubahan perilaku sebagai hasil belajar hanya mungkin terjadi jika ada interaksi antara pebelajar dengan sumber belajar. Inilah yang seharusnya diusahakan setiap pebelajar (instructor, pengajar) dalam kegiatan pembelajaran. Karena itu para pendidik maupun yang berkompeten dalam hal itu dituntut untuk kreatif menciptakan sumber belajar yang dapat dimanfaatkan pebelajar dalam memahami materi tertentu. Sumber belajar memiliki fungsi :

- Meningkatkan produktivitas pembelajaran dengan : (a) mempercepat laju belajar dan membantu pengajar menggunakan waktu secara lebih baik, (b) mengurangi beban pengajar dalam menyajikan informasi, sehingga lebih banyak membina dan mengembangkan gairah. 
- Memberikan kemungkinan pembelajaran sifatnya lebih individual, dengan: (a) mengurangi kontrol pengajar kaku dan tradisional, (b) memberikan kesempatan pebelajar untuk berkembang sesuai dengan kemampuannnya.

- Memberikan dasar ilmiah terhadap pembelajaran dengan: (a) perancangan cara pembelajaran lebih sistematis, (b) pengembangan bahan pengajaran yang dilandasi oleh penelitian.

- Memantapkan pembelajaran, dengan: (a) meningkatkan kemampuan sumber belajar; (b) penyajian informasi dan bahan lebih kongkrit.

- Memungkinkan belajar secara seketika, yaitu: (a) mengurangi kesenjangan antara pembelajaran bersifat verbal dan abstrak dengan realitas sifatnya kongkrit; (b) memberikan pengetahuan yang sifatnya langsung.

- Memungkinkan penyajian pembelajaran yang lebih luas, dengan menyajikan informasi yang mampu menembus batas geografis.

c. Pemanfaatan Blog Sebagai Sumber Belajar.

Dunia semakin modern ini pemanfaatan teknologi pendidikan pun tidak dielakkan lagi. Dengan adanya teknologi modern, arus informasi semakin tak dapat terbendung. Semua orang diseluruh dunia mengetahui apa yang diinginkan melalui internet. Internet dapat menghilangkan batas ruang dan waktu sehingga siapa pun dapat memanfaatkanya. Pemanfaatan internet dalam dunia pendidikan gencar dilakukan diberbagai negara. Bahkan internet menjadi bagian tidak dapat dipisahkan pada pendidikan. Blog salah satu produk yang dihasilkan internet dapat dimanfaatkan sebagai sumber belajar karena Blog dibuat siapa pun dengan sangat mudah dan yang paling penting Blog dapat dibuat gratis.

Fakta penggunaan internet di kalangan pebelajar, banyak dimanfaatkan untuk melakukan hal yang kurang produktif, seperti terlalu banyak chatting, friendster-an, bermain game online, dan mengakses pornografi. Blog jumlahnya berlipat 2 setiap 6 bulan, pemiliknya dari kalangan pebelajar dan remaja jumlahnya sangat signifikan, ini merupakan fenomena harus dimanfaatkan untuk meningkatkan kualitas pendidikan dengan membuat Blog berkualitas agar masyarakat pebelajar mudah memperoleh informasi dibutuhkan. Selain berkualitas, Blog harus juga menarik agar pebelajar makin betah belajar didunia maya. Berbagai referensi, jurnal, maupun hasil penelitian dapat dengan mudah di download diberbagai Blog. Cukup memanfaatkan search engine, materi dapat diperoleh cepat. Selain menghemat tenaga dan biaya dalam mencarinya, materi yang dapat ditemui cenderung lebih up to date. Adapun manfaat Blog bagi pebelajar adalah:

- meningkatkan pengetahuan,

- berbagi sumber diantara rekan sejawat,

- bekerjasama dengan pengajar di luar negeri,

- kesempatan mempublikasikan informasi secara langsung,

- mengatur komunikasi secara teratur, dan

- berpartisipasi dalam forum-forum lokal maupun internasional.

Di samping itu para pengajar juga dapat memanfaatkan Blog sebagai sumber bahan mengajar dengan mengakses rencana pembelajaran atau silabus online dengan metodologi baru, mengakses materi pembelajaran yang cocok untuk pebelajarnya, serta dapat menyampaikan ide-idenya. Sementara itu pebelajar juga dapat menggunakan internet untuk belajar sendiri secara cepat, sehingga akan meningkatkan dan memperluas pengetahuan, belajar berinteraksi, dan mengembangkan kemampuan dalam bidang penelitian. Blog juga dapat dimanfaatkan oleh para guru untuk media pembelajaran, yaitu Blog guru sebagai pusat pembelajaran. Guru dapat menuliskan materi belajar, tugas, maupun bahan diskusi di blognya, kemudian para muridnya bisa berdiskusi dan belajar bersama-sama di blog gurunya tersebut. Selain itu blog guru dan murid juga dapat saling berinteraksi. Guru, yang harus memiliki Blog, mengharuskan murid memiliki blognya masing-masing, sebagai sarana mengerjakan tugas-tugas yang diberikan oleh gurunya. Metode ini bisa memacu iklim kompetisi antar siswa, karena tentu saja para siswa ingin blognya menjadi yang terbaik. Setelah semua siswa memiliki Blog dibuatlah suatu komunitas blogger pebelajar. Ada sebuah Blog sebagai pusat pembelajaran (bisa berupa blog aggregator atau blog dengan beberapa kontributor), dengan guru-guru dan siswa dari berbagai sekolah bisa tergabung dalam komunitas blogger pebelajar tersebut. 


\section{Conventional Learning dan e-Learning}

Menyikapi perkembangan Teknologi Informasi dan komunikasi diatas, menyebabkan adanya perubahan metode konvensional dalam proses belajar mengajar yang digantikan dengan metode $e$ learning. Metode conventional learning yang mengharuskan pengajar dan pebelajar harus bertatap muka langsung di ruangan memiliki beberapa ciri, yaitu: 1) pembelajaran tergantung pada pengajar; 2) seluruh kegiatan belajar mengajar terpusat di dalam ruang; 3) pengajar merupakan sumber ilmu; 4) dibatasi jarak, ruang dan waktu; dan 5) harus memiliki sarana dan prasarana belajar mengajar yang memadai serta sumber daya manusia pengajaar yang memahami setiap materi pembelajaran yang akan diajarkan. Sedangkan ciri-ciri e-learning adalah: 1) pembelajaran tidak tergantung kepada pengajar; 2) banyaknya sumber materi dan kemudahan akses; 3) peran pengajar hanya sebagai mediator atau pembimbing; 4) proses belajar tidak terkendala jarak, ruang dan waktu. Merujuk dari ciri-ciri kedua metode di atas, maka nge-blog adalah sebuah alternatif metode proses belajar mengajar yang bersifat e-learning dan juga student centered. Penyelenggara pendidikan seperti Perguruan tinggi yang ingin menggunakan Teknologi Iinformasi dan Komunikasi untuk penerapan e-learning biasanya menggunakan Learning Management System (LMS) untuk menyediakan virtual classroom (ruang kelas virtual) di internet. Virtual classroom yang dimiliki biasanya memiliki banyak metafora ruang kelas konvensional seperti forum diskusi, pengumpulan tugas, katalog/perpustakaan bahan ajar, katalog hyperlink dan lain sebagainya.

\section{Fungsi Blog dalam Sistem Terintegrasi}

Jika pengajar sudah memiliki blog, maka yang harus difikirkan adalah bagaimana mengintegrasikan blog dalam proses belajar mengajar. Ada beberapa cara, diantaranya para pengajar dapat menggunakan blog untuk menampilkan informasi materi yang akan diberikan, bahan ajar yang siap diunduh pebelajar, daftar hyperlink sebagai referensi, memberikan tugas dan menampilkan hasil penelitan pengajar. Karena fitur pada blog memungkinkan memberikan pertanyaan dan komentar atas artikel atau bahan ajar yang tersedia, maka komunikasi pun akan berjalan dua arah dan interaktif, baik dari pengajar ke pebelajar atau sebaliknya.

Cara yang lain adalah ketika memberikan tugas kepada pebelajar, maka pengajar tersebut menerangkannya secara lisan dan kemudian menampilkannya pada blog. Pebelajar yang akan mengumpulkan tugas diminta untuk menampilkan jawaban dari tugas dalam blog pribadi pebelajar tersebut. Penilaian diberikan dengan cara pengajar tersebut mengunjungi blog pebelajar untuk kemudian memberikan komentar tentang jawaban tugas yang telah dibuat oleh pebelajar. Cara ini memberikan arti bahwa pebelajar tidak hanya bertanggung jawab atas jawaban tugas kepada pengajar saja, melainkan bertanggung jawab pula kepada publik/pengguna internet sebagai pembaca. Integrasi blog dalam aktifitas proses belajar mengajar seperti ini secara otomatis meningkatkan waktu "tatap muka" pengajar dan pebelajar. Diskusi yang terekam dalam fasilitas komentar yang tersedia pada blog juga dapat menjadi referensi tambahan bagi para pembaca blog dan dapat dilihat serta dibaca kapan saja. Selain mendidik dan mengenalkan pebelajar menulis melalui media internet, cara-cara ini juga mampu mendongkrak nama institusi pendidikan di dunia maya serta melatih pebelajar untuk berbagi ilmu dengan orang lain. Ketika membicarakan blog sebagai suatu sub-sistem yang terintegrasi, maka akan ada pula beberapa sub-sistem yang saling berkaitan serta saling memengaruhi. Proses belajar mengajar merupakan sebuah input dan output yang diharapkan adalah proses belajar mengajar yang berkualitas. Tentunya sistem tersebut harus memiliki karakteristik sebagai sistem yang memiliki umpan balik (feedback system). Dengan adanya integrasi antar sub-sistem tersebut diharapkan akan menghasilkan proses belajar mengajar yang tidak hanya melibatkan pengajar, tetapi juga pebelajar, untuk menghasilkan proses belajar mengajar yang lebih berkualitas.

\subsection{Pre \& Pos Tes.}

Pre Test yaitu suatu bentuk pertanyaan, yang dilontarkan guru kepada muridnya sebelum memulai suatu pelajaran. Pertanyaan yang ditanya adalah materi yang akan diajar pada hari itu (materi baru). Pertanyaan itu biasanya dilakukan guru di awal pembukaan pelajaran. Pre test diberikan dengan maksud untuk mengetahui apakah ada diantara murid yang sudah mengetahui 
mengenai materi yang akan diajarkan. Pre test juga bisa di artikan sebagai kegiatan menguji tingkatan pengetahuan siswa terhadap materi yang akan disampaikan, kegiatan pre test dilakukan sebelum kegiatan pengajaran diberikan. Adapun manfaat dari diadakannya pree test adalah untuk mengetahui kemampuan awal siswa mengenai pelajaran yang disampaikan. Dengan mengetahui kemampuan awal siswa ini, guru akan dapat menentukan cara penyampaian pelajaran yang akan di tempuhnya nanti.

Post test merupakan bentuk pertanyaan yang diberikan setelah pelajaran/materi telah disampaikan. Singkatnya, post test adalah evalausi akhir saat materi yang di ajarkan pada hari itu telah diberikan yang mana seorang guru memberikan post test dengan maksud apakah murid sudah mengerti dan memahami mengenai materi yang baru saja diberikan pada hari itu. Manfaat dari diadakannya post test ini adalah untuk memperoleh gambaran tentang kemampuan yang dicapai setelah berakhirnya penyampaian pelajaran. Hasil post test ini dibandingkan dengan hasil pree test yang telah dilakukan sehingga akan diketahui seberapa jauh efek atau pengaruh dari pengajaran yang telah dilakukan, disamping sekaligus dapat diketahui bagian bagian mana dari bahan pengajaran yang masih belum dipahami oleh sebagian besar siswa.

\subsection{Penyelesaian Masalah.}

Pengabdian kepada masyarakat $(\mathrm{PkM})$ dilaksanakan setiap semester, periode ini pembuatan blog pada SMAN 2 Kota Pagar Alam, karena SMAN 2 Pagar Alam memerlukan pemahaman Teknologi Informasi yang lebih untuk meningkatkan kualitas pembelajaran, dengan menggunakan blog agar siswa belajar dapat dilakukan dimana saja, sehingga pemahaman siswa terhadap siswa menjadi lebih baik sehingga meningkatkan mutu pembelajaran.

\section{PEMBAHASAN DAN HASIL.}

3.1. Realisasi \& Pemecahan Masalah.

Pengabdian dilakukan pada laboratorium komputer SMAN 2 Kota Pagar Alam dilakukan selama satu hari dari pagi sampai sore peserta merupakan Guru dan Staf SMAN 2 Kota Pagar Alam, pelatihan dimulai dengan melakukan pre tes pendahuluan yang dilakukan narasumber, pada pelatihan narasumber dibantu beberapa orang mahasiswa sebagai asisten, tes pertama ini dilakukan untuk mengetahui pemahaman peserta pelatihan pemahamannya terhadap pembuatan website, blog, dan e-learning. Berikutnya setelah diketahui hasil dilanjutkan persiapan pembuatan blog didahului dengan pengenalan teori website, blog dan e-learning. Berikutnya setelah mengetahui teori dilanjutkan dengan membuat blog dengan bimbingan narasumber yang didampingi mahasiswa, peserta dapat memasukan bahan atau materi pelajaran yang dibawa sehingga apa bila peserta melakukan perbaikan dan dapat bertanya pada narasumber, berikut rincian kegiatan:

Tabel 1. Rincian Kegiatan

\begin{tabular}{|l|l|c|}
\hline \multicolumn{1}{|c|}{ Waktu } & \multicolumn{1}{|c|}{ Materi } & Penyaji \\
\hline $08.00-09.00$ & Pre Test & \\
$09.00-09.30$ & Persiapan Membuat Blog & Yogi Isro' \\
\cline { 1 - 2 } $09.30-12.00$ & $\begin{array}{l}\text { Panduan Membuat Blogdan Tutorial Membuat Blog } \\
\text { dengan Wordpress }\end{array}$ & Mukti \\
$12.00-12.30$ & Ishoma & \\
$12.30-13.00$ & Post-test & \\
\hline
\end{tabular}

Pengabdian ini memecahkan permasalahan pada SMAN 2 Kota Pagar Alam yang meningkatkan pemahaman Guru dan Karyawan terhadap Teknologi Informasi dalam hal ini aplikasi pemanfaatan blog untuk mendukung pembelajaran, karena disadari oleh pimpinan SMAN 2 Kota Pagar Alam, pembelajaran pada era atau jaman sistem digital ini mengarah kepada arah teknologi informasi yang menggunakan sistem digital berbasis database, sehingga siswa dapat melakukan pembelajaran dimana saja, sehingga pembelajaran didalam kelas merupakan sebagai pembelajaran pendahuluan berikutnya untuk lebih memahamkan siswa dapat belajar diluar kelas dengan sarana blog ini, yang lebih lanjut dikenal dengan e-learning. Pada akhir pelatihan pembuatan blog ini dilakukan tes lagi, yaitu pos tes tujuannya untuk mengetahui tingkat 
keberhasilan dari pelatihan yang dilakukan, tes dilakukan terhadap seluruh peserta pelatihan dengan menjawab pertanyaan yang diberikan.

\subsection{Pembahasan \& Hasil.}

Hasil dari pengabdian yang dilakukan berdasarkan pelaksanaan yang tertuang dalam poin 3.1 diatas, maka sesuai dengan rincian kegiatan diatas kegiatan dilakukan dengan pre tes hasilnya peserta 5\% sudah mengetahui teknologi pembelajaran dengan website, tetapi belum pernah membuat dan menggunakan, sisa peserta belum memahami, mengetahui atau membuat website, sehingga pelatihan ini sangat perlu dilakukan pada SMAN 2 Kota Pagar Alam, berikutnya setelah tes adalah pemberian materi teori untuk memahamkan peserta pelatihan terhadap teori, atau pemahaman terhadap teori website, teori e-learning dan tentunya teori tentang blog.

Berikutnya setelah teori disampaikan dan dirasa oleh narasumber peserta pelatihan telah menguasai materi yang disampaikan dengan baik, selanjutnya mempraktekan secara langsung pembuatan blog, peserta diminta untuk mengikuti langkah-langkah yang diberikan narasumber dan modul, dan memasukan data kedalam blog yang dibuat merupakan materi yang diajarkan didalam kelas, dan hasilnya semua peserta merasa nyaman mempelajari blog, berikut rincian keberhasilan dapat dilihat pada tabel 2 berikut:

Tabel 2. Keberhasilan Pelaksanaan Kegiatan

\begin{tabular}{|l|l|}
\hline \multicolumn{1}{|c|}{ Materi } & \multicolumn{1}{|c|}{ Hasil } \\
\hline Pendahuluan & $\begin{array}{l}\text { Pendahuluan dilakukan pre tes untuk mengetahui pemahaman } \\
\text { dan pengetahuan peserta terhadap teknologi blog }\end{array}$ \\
\hline $\begin{array}{l}\text { Teori website, blog dan e- } \\
\text { learning. }\end{array}$ & $\begin{array}{l}\text { Peserta pelathan memahami teknologi website, blog dan e- } \\
\text { learning untuk dunia pendidikan dan pembelajaran, arah } \\
\text { pengembangan teknologi pendidikan dimasa berbasis sistem } \\
\text { digital yang memungkinkan pendidikan dilakukan dengan } \\
\text { jarak jauh. }\end{array}$ \\
\hline Pengenalan tools, fitur blog & $\begin{array}{l}\text { Peserta paham dengan fitur dan tools dalam blogger sehingga } \\
\text { mampu mendesain sarana pembelajaran pada blog dengan } \\
\text { sangat baik agar siswa nyaman dan mudah mengerti dengan } \\
\text { pelajaran yang ditampilkan pada blog. }\end{array}$ \\
\hline Praktek pembuatan blog & $\begin{array}{l}\text { Peserta mampu membuat blog pembelajaran yang ideal dan } \\
\text { menarik pada saat pembelajaran. }\end{array}$ \\
\hline Penutup & $\begin{array}{l}\text { Dilakukan tes lagi untuk mengetahui sejauh mana } \\
\text { kemampuan peserta pelatihan dalam menangkap pemahaman } \\
\text { dan materi yang disampaikan oleh narasumber. }\end{array}$ \\
\hline
\end{tabular}

Pada pelatihan ini peserta telah dapat membuat blog pembelajaran dengan baik, dan bila ada kekurangan bisa bertanya dengan narasumber dan setelah pelatihan siswa bisa mengakses blog pembelajaran Guru peserta pelatihan dengan nyaman, dan terbukti seluruh peserta mampu membuat blognya sendiri dan ini dapat dibuktikan juga dengan hasil dari pos tes, pos tes menunjukan $100 \%$ peserta pelatihan dapat menyelesaikan pembuatan blog dengan sangat baik, maka berikut hasil identifikasinya:

a. Para peserta Guru dan karyawan SMAN 2 Kota Pagar alam telah memiliki pengetahuan dan pengalaman pembuatan blog untuk informasi atau untuk saran pendukung pembelajaran.

b. Seluruh Peserta menjadi memiliki pemahaman yang lebih terhadap teknologi informasi khususnya dalam teknologi pembuatan blog yang up to date.

c. Para peserta menjadi lebih percaya diri karena memiliki pemahaman baru dalam bidang teknologi informasi, padahal latar belakang pendidikan rata-rata bukan teknologi informasi

d. Saran pembelajaran pada SMAN 2 Pagar Alam menjadi lebih banyak, ini meningkatkan daya saing dan kepercayaan calon siswa \& orang tua yang belajar pada SMAN 2 Kota Pagar Alam. 
e. Sarana blog pembelajaran sebagai pendukung ini memudahkan siswa untuk belajar dimana saja, setelah didahului dengan belajar didalam kelas, siswa menjadi lebih paham lagi terhadap materi yang disampaikan.

\section{KESIMPULAN}

Pada pelaksanaan pengabdian masyarakat (PkM) ini yang dilakukan pada SMAN 2 Kota Pagar Alam, yang melatih para Guru dan karyawan SMAN 2 Kota Pagar Alam untuk memahami Teknologi Blog, yang diaplikasikan untuk sarana pembelajaran bagi para guru dan sarana menyampaikan informasi yang efektif bagi para staf karyawan, maka dapat disimpulkan sebagai berikut:

a. Pengenalan dan Pelatihan Teknologi Blog pada awalnya dari hasil tes peserta merasa pesimis bisa, tetapi setelah dilakukan praktek justru peserta merasa nyaman dan merasa mudah memahami blog sehingga bersemangat.

b. Pelatihan telah menambah softskills para Guru dan Karyawan terhadap teknologi baru, teknologi blogging, dan menumbuhkan rasa percaya diri pada saat pergaulan di masyarakat menghilangkan istilah gaptek.

c. Sarana pembelajaran blog diyakini dapat meningkatkan output SMAN 2 Kota Pagar Alam menjadi lebih baik, karena memiliki sarana pembelajaran yang banyak.

\section{SARAN}

Berdasarkan pelaksanaan pengabdian ini, sehingga pengabdi memiliki sarana kepada seluruh pemangku kepentingan dalam pelaksanaan pengabdian (PkM), Sekolah Tinggi Teknologi Pagaralam, sebagai berikut:

a. Pelaksanaan pengabdian dilakukan lebih lama dan ada kebebasan dalam pelaksanaan pengbdian, yang penting dalam 1 semeter.

b. Diperluas dan diperbanyak daerah binaan, sehingga menjadi sarana promosi juga kegiatan pengabdian yang dilaksanakan.

\section{UCAPAN TERIMA KASIH}

Terima kasih SMAN 2 Kota Pagar Alam, Terima Kasih LPPM STTP, Terima kasih pendukung PkM.

\section{DAFTAR PUSTAKA}

[1] M.H Jogiyanto, 1995, Pengenalan Komputer, Andi Offset Yogyakarta.

[2] Horsley, M., Knight, B., \& Huntly, H. 2010. The role of textbooks and other teaching and learning resources in higher education in Australia: Change and continuity in supporting learning. IARTEM 1-Journal. 3(2). 43-61.

[3] Muslim, B. 2018. Pelatihan aplikasi editing video dengan filmora., Laporan Pengabdian Kepada Masyarakat, LPPM STT Pagaralam.

[4] Muslim, B (2014). Analisis rencana aplikasi teknologi informasi pada STT Pagar Alam. Proseding semnastik dan Magma. Issue: Aplikasi Teknologi dan sistem Informasi. PPP UBD Pres. Pages 397-404.

[5] Hutchinson E. Sarah and Sawyer C. Stacey, 2000, Computers, Communications \& Information, McGraw Hill Companies Inc.

[6] Indonesia Services Education HP Tim, 2001, Manajemen Sistem Belajar Di Dunia Maya, Majalah Info Komputer.

[7] Muslim, B. 2018. Pelatihan Pembuatan Blog Bagi Guru Ma Ponpes Darul Mutaqin Kota Pagaralam. NGABDIMAS. Vol 1. No.1. Bulan Juni, Hal. 6-11

[8] B. Muslim, Pengantar teknologi informasi. Yogyakarta: Deepublish, 2017. 
[9] Muslim, B. (2018). Analisis system informasi (SI) terintegrasi di Perguruan Tinggi (PT) (Studi Kasus: STT Pagaralam). Jurnal Teknologi Informasi MURA, Vol 10. Page 83-91.

[10] Sadiman, A.S., Rahardjo, R., Haryono, A., \& Rahardjito. 2006. Media pendidikan: Pengertian, pengembangan, dan pemanfaatan. Jakarta: Rajagrafindo Persada.

[11] Menristekdikti. 2016. Panduan Pelaksanaan Penelitian dan Pengabdian Masyarakat di Perguruan Tinggi Edisi X Tahun 2016. hlm. 4.

[12] Michael Simkins, Karen Cole, Fern Tavalin and Barbara Means, Increasing Student Learning Through Multimedia Projects Diakses dari http://www.ascd.org/publications/books/102112/ chapters/What_Is Project-Based_Multimedia_Learning\%25C2\%25A2.aspx, tanggal 31 Agustus 2011.

[13] Gilbert, D. (2002). Multimedia Technology, Queensland: University of Queensland

[14] Eleanor L. Criswell (1989), Design of Computer-Based Instruction, Macmillan Pub Co, 1989.

[15] Unesco, Introduction | The multimedia approach, diakses dari www.unesco.org/education/tlsf/TLSF/intro/mod02/uncom, tanggal 1 September 2020.

[16] Suyanto, Analisis dan Desain Aplikasi Multimedia untuk Pemasaran, Andi Offset Yogyakarta 2004.

[17] Richard E. Mayer, Roxana Moreno, 1998, Aids to computer-based multimedia learning, Richard E. Mayer*, Roxana MorenoDepartemen Psikologi, University of California, Santa Barbara, CA 93106, USA Department of Psychology, University of California, Santa Barbara, CA 93106, USA 